\title{
EFFECT OF NUCLEOSIDES AND NUCLEOSIDE BASES ON THE DEVELOPMENT OF PRE-IMPLANTATION MOUSE EMBRYOS IN VITRO
}

\author{
JOAN THOMSON TENBROEGK
}

\author{
King Ranch Laboratory of Reproductive Physiology, Department of Animal Biology, \\ School of Veterinary Medicine, University of Pennsylvania, \\ Philadelphia, Pennsylvania, U.S.A.
}

(Received 22nd fuly 1968)

The nutritional requirements for the development in vitro of 2-celled mouse embryos into blastocysts have been extensively investigated by Brinster $(1965 \mathrm{a}, \mathrm{b}, \mathrm{c})$. It was found that most 2-celled embryos will develop normally in a culture medium consisting of bicarbonate-buffered Krebs-Ringer solution, containing bovine serum albumin as a protein source, and pyruvate and lactate as energy sources. Since there are always some 2-celled embryos which will not develop into blastocysts in this medium, the possibility exists that some other growth factors might increase the percentage of normally developing embryos. It is known that synthesis of DNA takes place throughout the cleavage stages and that RNA synthesis also occurs, especially after the 4-cell stage (Mintz, 1964). Thus it was thought that the addition of nucleic acid components to the culture medium might be beneficial for development.

Two-celled embryos for the experiments were collected from Swiss mice which had been superovulated and mated with Swiss males 2 days previously (Brinster, 1963). Embryos were cultured in small drops of medium under paraffin oil in $15 \times 60 \mathrm{~mm}$ plastic tissue culture dishes. The cultures were maintained at $37^{\circ} \mathrm{C}$ in an atmosphere of humidified $5 \% \mathrm{CO}_{2}$ in air for 3 days, the time necessary for the formation of blastocysts from 2-celled embryos. To test single components, the compounds were added to culture medium at a concentration of $10^{-2} \mathrm{M}$, except for guanosine, which was insoluble above $10^{-3} \mathrm{M}$. In all cases the solutions were adjusted to maintain the optimum $\mathrm{pH}$ and osmolarity. To determine dose-response relationships for the compounds, a series of four tenfold dilutions was made from each of the initial solutions. Embryos were cultured in the various concentrations of the compounds for 3 days. In each case twelve embryos were placed in a drop, and two drops were allotted to each treatment. The entire series of experiments was repeated, so that a total of forty-eight embryos received each treatment. The experiments were scored by counting the number of morphologically normal blastocysts which developed in each drop. The fractional scores were converted to angles (Biggers \& Brinster, 1965), and the data for each compound were subjected to an analysis of variance.

To test a combination of compounds, the bases adenine, cytosine, thymine and uracil were added to the culture medium, each at a concentration of $10^{-3} \mathrm{M}$; 
guanine concentration was less than $10^{-3} \mathrm{M}$, because of the relative insolubility of this compound in aqueous solutions. Four ten-fold dilutions of this medium were made, and the effects of the various media on in vitro development were tested. The experimental design and analysis were identical with those of the single-component experiments. The effect of nucleoside combinations was tested

TABLE 1

EFFECT OF SOME PURINE AND PYRIMIDINE BASES ON THE DEVELOPMENT OF 2-CELL MOUSE EMBRYOS INTO BLASTOCYSTS in vitro

\begin{tabular}{l|c|c|c|c|c|c}
\hline & \multicolumn{6}{|c}{ Percentage of embryos forming blastocysts } \\
\cline { 2 - 7 } \multicolumn{1}{c|}{ Treatment } & 0 & $10^{-6} M$ & $10^{-5} M$ & $10^{-4} M$ & $10^{-3} M$ & $10^{-2} M$ \\
\hline Adenine & $52 \cdot 1$ & $39 \cdot 6$ & $47 \cdot 9$ & $29 \cdot 2$ & $10 \cdot 4$ & 0 \\
Cytosine & 37.5 & - & $33 \cdot 3$ & $22 \cdot 9$ & $27 \cdot 1$ & $22 \cdot 9$ \\
Thymine & $62 \cdot 5$ & $66 \cdot 7$ & $45 \cdot 8$ & $54 \cdot 2$ & $56 \cdot 2$ & $2 \cdot 08$ \\
Uracil & 62.5 & $62 \cdot 5$ & $70 \cdot 8$ & $77 \cdot 1$ & $72 \cdot 9$ & 0 \\
\hline
\end{tabular}

TABLE 2

EFFEGT OF SOME NUCLEOSIDES ON THE DEVELOPMENT OF TWO-CELL MOUSE EMBRYOS INTO BLASTOCYSTS in vitro

\begin{tabular}{l|c|c|c|c|c|c}
\hline \multirow{2}{*}{ Treatment } & \multicolumn{6}{|c}{ Percentage of embryos forming blastocysts } \\
\cline { 2 - 7 } & 0 & $10^{-6} M$ & $10^{-5} M$ & $10^{-4} M$ & $10^{-3} M$ & $10^{-2} M$ \\
\hline Adenosine & $68 \cdot 7$ & $50 \cdot 0$ & $60 \cdot 4$ & $2 \cdot 08$ & 0 & 0 \\
Gytidine & $62 \cdot 5$ & $75 \cdot 0$ & $77 \cdot 1$ & $72 \cdot 9$ & $58 \cdot 3$ & 0 \\
Guanosine & $81 \cdot 2$ & $77 \cdot 1$ & $83 \cdot 3$ & $41 \cdot 7$ & $4 \cdot 17$ & $\frac{1}{18 \cdot 7}$ \\
Thymidine & $56 \cdot 2$ & - & $35 \cdot 4$ & $43 \cdot 7$ & $35 \cdot 4$ & $18 \cdot 7$ \\
Uridine & $39 \cdot 6$ & - & $20 \cdot 8$ & $35 \cdot 4$ & $10 \cdot 4$ & $2 \cdot 08$ \\
\hline
\end{tabular}

TABLE 3

EFFEGT OF BASE AND NUCLEOTIDE COMBINATIONS ON THE DEVELOPMENT OF 2-CELL MOUSE EMBRYOS INTO BLASTOCYSTS in vitro

\begin{tabular}{l|c|c|c|c|c|c}
\hline \multirow{2}{*}{ Treatment } & \multicolumn{6}{|c}{ Percentage of embryos forming blastocysts } \\
\cline { 2 - 7 } & 0 & $10^{-7} M$ & $10^{-6} M$ & $10^{-5} M$ & $10^{-4} M$ & $10^{-3} M$ \\
\hline Bases & $66 \cdot 7$ & $47 \cdot 9$ & $39 \cdot 6$ & $31 \cdot 2$ & $35 \cdot 4$ & $20 \cdot 8$ \\
Nucleosides & $66 \cdot 7$ & $56 \cdot 2$ & $47 \cdot 9$ & $52 \cdot 1$ & $16 \cdot 7$ & $2 \cdot 08$ \\
\hline
\end{tabular}

by adding adenosine, cytidine, guanosine, thymidine and uridine to the medium, each at a concentration of $10^{-3} \mathrm{M}$. The medium was diluted and tested as previously described.

The results of the experiments with single bases and nucleosides are presented in Tables 1 and 2. Most of the compounds were increasingly inhibitory as the concentration was raised. The two main exceptions were cytidine and uracil, but, although the lower concentrations of both compounds resulted in an 
increase in the number of blastocysts forming, these differences were not statistically significant.

The results of experiments using combinations of compounds are shown in Table 3. In the case of both nucleosides and bases, the compounds were increasingly inhibitory as the concentrations were increased.

The experiments have thus shown that the presence of nucleic acid precursors in the culture environment, either singly or in combination, does not enhance development of the pre-implantation mouse embryo. Since experiments with labelled nucleosides have shown that these compounds are incorporated by the early mouse embryo (Mintz, 1964; Monesi \& Salfi, 1967), the lack of beneficial effect cannot be due to impermeability of the embryos to the compounds. It therefore appears likely that the early embryo either contains an adequate endogenous supply or is able to synthesize the components required for the formation of DNA and RNA.

This investigation was supported in part from a grant from the National Institutes of Health (HD-02315-02). The author acknowledges the excellent technical assistance of Miss Mary Ryans, Mrs Margaret van Meter and Miss Shelly Walker.

\section{REFERENCES}

BigGers, J. D. \& Brinster, R. L. (1965) Biometrical problems in the study of early mammalian embryos in vitro. F. exp. Zool. 158, 39.

BRINSTER, R. L. (1963) A method for in vitro cultivation of mouse ova from two-cell to blastocyst. Expl Cell Res. 32, 205.

Brinster, R. L. (1965a) Studies on the development of mouse embryos in vitro. II. The effect of energy source. F. $\exp$. Zool. 158, 59.

BRINSTer, R. L. (1965b) Studies on the development of mouse embryos in vitro. III. The effect of fixed-nitrogen source. F. exp. Zool. 158, 69 .

BRINSTER, R. L. (1965c) Studies on the development of mouse embryos in vitro. IV. Interaction of energy sources. F. Reprod. Fert. 10, 227.

Mintz, B. (1964) Synthetic processes and early development in the mammalian egg. F. exp. Zool. 157, 85.

MONESI, V. \& SALFI, V. (1967) Macromolecular syntheses during early development in the mouse embryo. Expl Cell Res. 46, 632. 